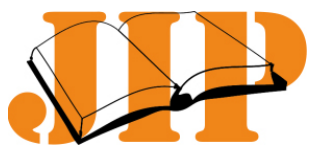

JURNAL ILMU PEMERINTAHAN:

Kajian Ilmu Pemerintahan dan Politik Daerah

Volume 3- Nomor 1, April 2018, (HIm 43-55)

Available online at: http://e-journal.upstegal.ac.id/index.php/jip

Submission: 09-02-2018; Revision: 27-03-2018; Publish: 30-05-2018

DOI: http://dx.doi.org/10.24905/jip.v3i1.883

\title{
Politisasi Program Keluarga Harapan Pra-Pilkada Gubernur Jatim 2018: Studi Kasus Kota dan Kabupaten Malang
}

\author{
Wimmy Halim \\ Program Studi Ilmu Politk, Universitas Brawijaya. Jln Veteran, Kota Malang, Jawa Timur, \\ 65145, Indonesia \\ * Korespondensi Penulis. E-mail: wimmyfisip@ub.ac.id.
}

\begin{abstract}
Abstrak
Program Keluarga Harapan (PKH) sebagai kebijakan penanggulangan kemiskinan memiliki celah dibalik keberhasilannya menekan kemiskinan di Kota dan Kabupaten Malang. Fakta yang didapatkan penulis menyatakan, bahwa elit politik yang berkepentingan dalam Pilkada Gubernur Jawa Timur tahun 2018 memanfaatkan PKH sebagai alat politiknya. Diantaranya adalah Khofifah Indar Parawansa sebagai Menteri Sosial dan Rendra Kresna sebagai Bupati Kabupaten Malang. Dengan metode penulisan studi kasus, penulis menjelaskan beberapa hasil dan pembahasan didalam penulisan artikel ini. Pertama, bahwa potensi PKH sebagai alat politik memang sudah terjadi sejak era pemerintahan Susilo Bambang Yudhoyono (SBY). Kedua, penulis juga menjelaskan dampak politisasi dari PKH. Ketiga, adalah tuntutan penulis untuk merubah orientasi PKH dari bantuan tunai langsung menjadi pemberdayaan. Penulis yakin dengan merubah orientasi PKH menjadi pemberdayaan, maka PKH memiliki capaian jangka panjang dan membentuk masyarakat miskin menuju masyarakat yang mandiri dan berdaya.
\end{abstract}

Kata kunci: Kemiskinan; Pemberdayaan Masyarakat

\section{Politicization of Family Program of Pre-Election of Regional Head Governor East Java 2018: Case Study of City and Regency Malang}

\begin{abstract}
Family Hope Program (PKH) as a poverty reduction policy has a gap behind its success in reducing poverty in Malang City and Regency. The facts obtained by the author, that the political elite concerned in the elections of Governor of East Java in 2018 utilize PKH as a political tool. Among them are Khofifah Indar Parawansa as Minister of Social Affairs and Rendra Kresna as Regent of Malang Regency. With the method of case studies, the authors explain some of the results and discussion in this article. First, that the potential of PKH as a political tool has been happening since the Susilo Bambang Yudhoyono (SBY) governments era. Second, the author also explains the politicized impact of PKH. Third, it is the author's request to change the PKH orientation from direct cash assistance to empowerment. The author believes that by changing the PKH orientation to empowerment, PKH has long-term outcomes and shapes the poor to an independent and empowered community.
\end{abstract}

Keywords: Poverty; Empowerment 


\section{PENDAHULUAN}

Kebijakan pemerintah melalui Kementrian Sosial dalam meminimalisir permasalahan - $\quad$ permasalahan kesejahteraan sosial, khususnya kemiskinan yang terus bertambah dari hari ke hari, salah satunya adalah Program Keluarga Harapan (PKH). Program ini berupaya untuk mengembangkan sistem perlindungan sosial terhadap warga miskin di Indonesia. Program ini dilaksanakan oleh Dinas Sosial yang merupakan salah satu instansi pemerintah yang bergerak di bidang sosial. Kedudukan PKH merupakan bagian dari program-program penanggulangan kemiskinan lainnya. PKH merupakan program lintas Kementerian dan Lembaga karena aktor utamanya adalah dari Badan Perencanaan Pembangunan Nasional, Departemen Sosial, Departemen Kesehatan, Departemen Pendidikan Nasional, Departemen Agama, Departemen Komunikasi dan Informatika, dan Badan Pusat Statistik. Untuk mensukseskan program tersebut, maka dibantu oleh Tim Tenaga Ahli PKH dan konsultan World Bank (Ambarwati, 2014)

PKH dijalankan sebagai pelaksanaan dari UU no. 40 tahun 2004 tentang jaminan sosial. UU no. 11 tahun 2009 tentang kesejahteraan sosial. Inpres no. 3 tahun 2010 tentang program pembangunan yang berkeadilan. Perpres no. 15 tahun 2010 tentang percepatan penanggulangan kemiskinan dan UU no. 39 tahun 1999 tentang hak asasi manusia.Program ini memberikan bantuan uang tunai kepada Rumah Tangga Sangat Miskin (RTSM) dengan catatan mengikuti persyaratan yang diwajibkan. Persyaratan itu terkait dengan peningkatan kualitas sumber daya manusia yaitu kesehatan dan pendidikan. PKH dalam jangka pendek dapat mengurangi beban RTSM dan dalam jangka panjang diharapkan dapat memutus rantai kemiskinan antar generasi sehingga generasi berikutnya dapat keluar dari perangkap kemiskinan. PKH menjangkau dua aspek sekaligus yakni kesehatan dan pendidikan di keluarga miskin. Sasaran dari program ini yakni ibu hamil, ibu menyusui, memiliki anak balita dan anak usia sekolah setingkat SD-SMP. Penerima bantuan ini adalah ibu atau wanita dewasa yang mengurus anak pada rumah tangga yang bersangkutan. Namun apabila tidak ada ibu, bibi, nenek atau kakak perempuan dapat menjadi penerima bantuan.

Program sejenis PKH pertama kali diimplementasikan di sejumlah negara Amerika Latin dan Karibia seperti Meksiko, Brazil, Kolumbia, Honduras, Jamaica, dan Nikaragua yang dikenal dengan program Conditional Cash Transfer (CCT) atau Bantuan Tunai Bersyarat. Program memiliki sasaran RTSM. Di Indonesia PKH memiliki persyaratan yang mengharuskan penerima melakukan pemeriksaan kesehatan bagi ibu hamil dan balita dan meningkatkan kehadiran sekolah secara teratur bagi anakanak RTSM yang memiliki usia SD-SMP.

Di Indonesia PKH mulai dilaksanakan di 7 provinsi pada tahun 2007. Sedangkan di Kota Malang PKH dimulai tahun 2013 dan berlangsung sampai saat ini. Pemerintahan Kota Malang merespons masalah kemiskinan tersebut dengan menggulirkan PKH yang merupakan pengembangan sistem perlindungan sosial yang dapat meringankan dan membantu masyarakat miskin dalam hal mendapatkan akses pelayanan kesehatan dan Pendidikan Dasar. Program ini merupakan implementasi Perpres Nomor 15 Tahun 
2010 tentang percepatan penanggulangan kemiskinan dan Keputusan Walikota Malang Nomor: 188.45 / 159/ 35.73.112 / 2014 tentang Tim Pelaksana Kegiatan Operasional Program Keluarga Harapan. Program ini dilatarbelakangi oleh adanya permasalahan utama pembangunan yaitu masih besarnya jumlah penduduk miskin serta rendahnya kualitas SDM.

Secara administratif, PKH cenderung minim akan kekurangan. Aspek teknis dalam PKH sudah dibuat cukup detail. PKH sudah menjawab unsur-unsur pelaksanaan kebijakan yang baik. Bahwa sebuah pelaksanaan kebijakan yang baik akan memiliki aktifitas atau usaha-usaha yang dilaksanakan untuk melaksanakan semua rencana dan kebijaksanaan yang telah dirumuskan dan ditetapkan dengan dilengkapi segala kebutuhan(Matualage, 2015). Dalam perspektif implementasi kebijakan, PKH dapat dinilai sebagai kebijakan yang berhasil, alasannya PKH berhasil menjelaskan kesesuaian dari tiga unsur dalam kebijakan tersebut, yaitu: (1) kesesuaian antara program dengan pemanfaat. (2) kesesuaian antara program dengan organisasi pelaksana. kesesuaian antara kelompok pemanfaat dengan organisasi pelaksana. (Rahmadiani, 2016)

Kemudian, PKH sebagai sebuah kebijakan sudah bisa menjawab beberapa tahapan dalam pembuatan kebijakan, yaitu: (Nugroho, 2014) (a) Merancang bangun (design) program beserta perincian tugas dan perumusan tujuan yang jelas. Tujuan PKH jelas, yaitu menurunkan angka kemiskinan. (b) Melaksanakan (application) program dengan mendayagunakan struktur-struktur dan personalia, dana serta sumber-sumber lainnya. Struktur hierarki pelaksanaan PKH juga sudah jelas, yaitu melalui dinas-dinas sosial didaerah. (c) Membangun sistem penjadwalan, monitoring dan sarana-sarana pengawasan yang tepat guna serta evaluasi (hasil) pelaksanaan. Hal tersebut telah dilaksanakan oleh Unit Pelaksana Program Keluarga Harapan (UPPKH) yang ada disetiap daerah, termasuk Kota dan Kabupaten Malang.

Namun, penulis percaya bahwa keberhasilan sebuah kebijakan tidak hanya ditentukan dari keberhasilan administrasinya saja, tetapi juga harus dinilai dari dampak sosial terhadap masyarakat sebagai pihak yang terdampak dari sebuah kebijakan. Dalam konteks PKH, dampak sosial ini bisa dilihat dari seberapa banyak turunnya angka penerima bantuan PKH. Dapat diasumsikan bahwa jika dari tahun per tahun penerima bantuan PKH semakin berkurang, bisa dikatakan bahwa PKH adalah program unggulan dari Kementrian Sosial. Namun sebaliknya, jika penerimanya semakin bertambah, maka bisa dikatakan PKH perlu untuk di evaluasi dan semua pihak perlu mengetahui apa yang menyebabkan angka kemiskinan semakin bertambah.

Awal pelaksanaan PKH di Kota Malang tahun 2013 hingga 2015, angka penerima PKH terus membuahkan hasil positif. Penerima bantuan dari tahun ke tahun selalu mengalami penurunan(Haliim, 2016). Tapi yang mengherankan adalah rencana Pemerintah Daerah Kota Malang yang akan meningkatkan jumlah penerima bantuan PKH sebanyak 1800 kepala keluarga (Surya Malang, n.d.) 


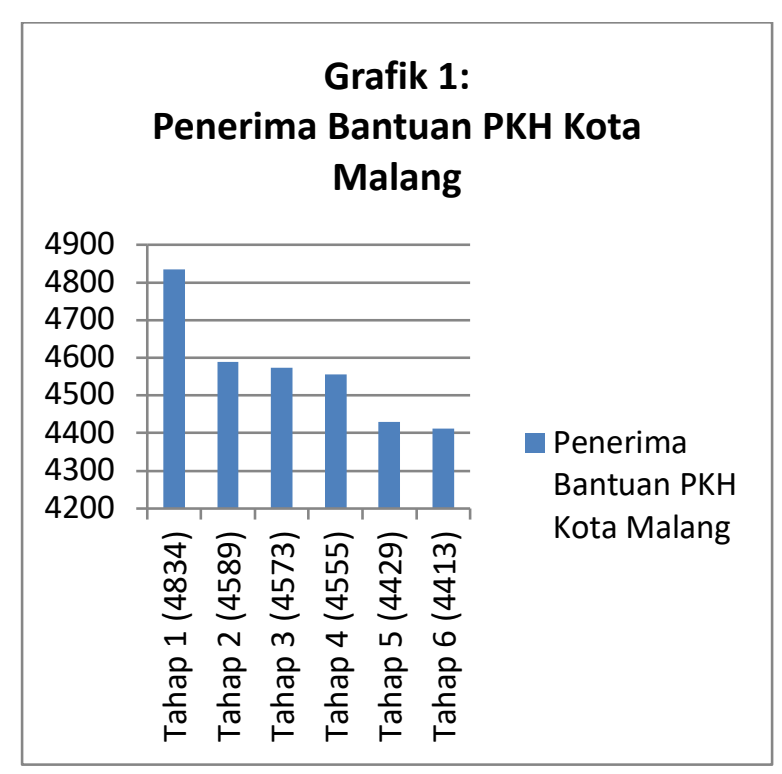

(Sumber: Dinas Sosial Kota Malang, 2015)

Tidak jauh dari Kota Malang, Kabupaten Malang Juga melakukan kebijakan yang serupa. Jumlah penerima PKH Kabupaten Malang tahun depan bertambah sekitar 31 ribu warga, setelah pada tahun 2017 jumlah penerima PKH di Kabupaten Malang mencapai 55.441 warga (Muiz, 2017). Informasi-informasi diatas juga didukung oleh rencana kebijakan nasional PKH kementrian sosial Republik Indonesia yang meningkatkan penerima bantuan PKH dari 6 Juta menjadi 10 Juta penerima bantuan.

Informasi diatas yang menyebutkan bahwa bantuan PKH akan ditingkatkan justru menimbulkan kecurigaan bagi penulis, bahwa PKH sedang dimuati oleh kepentingan politik. Pertama, Kebijakan peningkatan bantuan $\mathrm{PKH}$ semakin mencurigakan dikala kebijakan tersebut disosialisasikan setahun sebelum pemilihan langsung kepala daerah (Pilkada) Gubernur Jawa Timur. Kedua, ada motif kepentingan politik dibalik setiap agenda PKH. Fakta yang ada dilapangan mengungkapkan bahwa Bupati Kabupaten Malang, Rendra Kresna (sekaligus ketua DPW Partai NasDem), ketika menyambut Menteri
Sosial, Khofifah Indar Parawansa (sekaligus calon Gubernur Jawa Timur) dalam salah satu agenda PKH Kabupaten Malang, secara tersirat mengarahkan audiens yang hadir pada waktu itu untuk mendukung Khofifah Indar Parawansa (Muhammad Aminudin, 2017). Perlu untuk diketahui, bahwa partai NasDem adalah salah satu partai yang sudah menyatakan diri untuk mengusung Khofifah Indar Parawansa untuk menjadi calon Gubernur Jatim di pilkada tahun 2018 mendatang. Atas dasar informasi dan fakta yang sudah diurai penulis, maka dari itu penulis tertarik untuk membahas dan mengkaji kepentingan politik elit politik yang secara langsung memanfaatkan PKH guna kepentingan Pilkada Gubernur Jatim 2018, terutama di Kota dan Kabupaten Malang.

\section{METODE}

Metode studi kasus berfokus kepada spesifikasi kasus dalam suatu kejadian, baik yang mencakup kasus yang dialami oleh individu maupun sebuah kelompok masyarakat (Lewis, 2015). Creswell dalam (Mulyadi, 2011) juga mengemukakan bahwa metode studi kasus memiliki beberapa karakteristik, yaitu yang pertama penulis berusaha untuk mengidentifikasi spesifikasi kasus untuk kepentingan sebuah studi. Kedua, memberikan informasi dan gambaran terperinci dan mendalam tentang dinamika dari suatu peristiwa. Ketiga, metode studi kasus dapat menggambarkan secara jelas setting maupun konteks untuk suatu kasus yang mengisyaratkan bahwa suatu kasus dapat dikaji menjadi sebuah objek studi.

Penulisan artikel ini memiliki dua batasan, yaitu batasan lokasi dan batasan pembahasan. Batasan lokasi yang 
dimaksud, penusilan artikel hanya difokuskan di Kota dan Kabupaten Malang. Batasan yang kedua adalah pembatasan pembahasan penulisan artikel yang memfokuskan pada agenda politik yang dilakukan oleh Khofifah Indar Parawansa (selaku penanggung jawab PKH Nasional) dan elit politik yang berkepentingan melalui agenda-agenda PKH beserta dampaknya terhadap pelaksanaan PKH di Kota dan Kabupaten Malang dikemudian hari. Metode pengumpulan data dilakukan penulis dengan cara observasi lapangan, wawancara, dan studi literatur.

\section{HASIL DAN PEMBAHASAN}

\section{PKH Sebagai Alat Politik}

Pertama, penulis akan sedikit mengulas tentang sejarah awal mula PKH yang terindikasi sebagai alat politik di era pemerintahan Susilo Bambang Yudhoyono (SBY). Karena dalam penjelasan tersebut, kita akan bisa memahami bahwa PKH adalah salah satu kebijakan menteri sosial yang memiliki celah krusial hingga saat ini, yaitu dapat digunakan penguasa sebagai alat politik. Kedua, penulis akan menjelaskan bagaimana efektifitas seorang elit menggunakan $\mathrm{PKH}$ sebagai alat politiknya, terutama Khofifah dan elit politik yang memiliki kepentingan politik di pilkada gubernur jatim 2018 di Kota dan Kabupaten Malang. Poin ini akan menjadi penegasan bahwa PKH diimplementasikan tidak hanya sekedar menjadi program unggulan pemerintah untuk menekan angka kemiskinan, namun juga bisa digunakan penguasa untuk kepentingan politik tertentu.

$\mathrm{PKH}$ yang tengah dicanangkan pemerintahan SBY pada waktu itu memang telah menyedot perhatian publik. Banyak argumen yang berbeda dari para analis kebijakan yang menanggapi kebijakan tersebut secara positif maupun negatif. Beberapa pendapat mengatakan bahwa kebijakan PKH hanya digunakan pemerintahan SBY meningkatkan popularitas SBY secara personal sebagai seorang politisi. Secara politik, perencanaan PKH juga didukung oleh fraksi partai Demokrat beserta koalisi didalam parlemen.

Namun, pada waktu itu ekonom Asosiasi Ekonomi Politik Indonesia (AEPI), Ichsanuddin Noorsy (Rahayu, 2015), berpendapat bahwa, PKH dibentuk oleh pemerintah tersebut untuk mereduksi tekanan rakyat kepada pemerintah terkait rencana kebijakan pembatasan bahan bakar minyak (BBM) bersubsidi yang cenderung tidak pro rakyat. Jadi bisa dinilai bahwa, PKH yang merupakan kebijakan baru pengganti BLT merupakan kebijakan yang politis dan tidak efektif untuk menekan angka kemiskinan didaerah. Belum lagi, pembentukan PKH dilakukan ketika popularitas SBY sedang menurun (Rahayu, 2015). (Rosfadhila, M Toyamah, 2011) juga menegaskan bahwa PKH maupun BLT sukses mendongkrak elektabilitas SBY pada pemilu 2009. Dari pemaparan para pengamat diatas pada akhirnya $\mathrm{PKH}$ mendapatkan branding sebagai kebijakan politis yang bisa digunakan penguasa sesuai dengan kepentingan politiknya.

Pasca pemilu terakhir yang diikuti SBY dengan menggunakan PKH sebagai alat politiknya, citra politis $\mathrm{PKH}$ ternyata mulai direduksi di era pemerintahan Jokowi dengan Khofifah Indar Parawansa sebagai Mentri Sosialnya. Khususnya di Kota dan Kabupaten Malang. Catatan (Rahmadiani, 2016) mengungkapkan, bahwa PKH 
membantu menekan angka kemiskinan yang ada di Kota malang sekitar 5\% pertahunnya. Selain memberikan bantuan tunai kepada Rumah Tangga Sangat Miskin (RTSM), PKH juga memiliki program Elektronik Warung Gotong Royong Kelompok Usaha Bersama Program Keluarga Harapan (e-Warong Kube-PKH) yang merupakan pengembangan dari PKH (M. Sulton Mawardi, Ruhmaniyati, Ana Rosidha Tamyis, Syaikhu Usman, Asep Kurniawan, 2017)

Namun, manuver politik Khofifah sudah mulai terlihat di Jawa Timur pada pertengahan tahun 2016 hingga tahun 2017 via agenda PKH. Di Kota dan Kabupaten Malang, beberapa agenda PKH yang dihadiri langsung Khofifah sebagai Menteri Sosial. Diantaranya, peresmian e-Warong KubePKH bulan juni 2016 (Tribunnews, n.d.), kebijakan Kabupaten Malang menerima tambahan penerima bantuan PKH pada agustus 2017 (Miski, Deny Rahman, 2017), dan penyerahan bantuan PKH di Kabupaten Malang pada November 2017(Avirista Midaada, 2017). Penulis melihat hadirnya menteri sosial bukan hanya sekedar tugas kenegaraan saja, melainkan ada kepentingan politik untuk meraih popularitas dikalangan penerima bantuan PKH.

Fakta diatas sekali lagi mengingatkan kita tentang kebijakan BLT pada tahun 2009 yang membantu ikut mendongkrakan elektabilitas Incumbent, SBY, pada pemilu Presiden 2009. Dalam momentum pilkada jatim 2018 mendatang, Fenomena dimana PKH sebagai alat politik elit-elit yang berkepentingan di Jawa Timur akhirnya bisa dilhat sebagai sebuah fakta politik. Jika keadaan tersebut yang terjadi, kebijakan pro-poor seperti PKH akan disangsikan keberhasilan dan keberlanjutannya dikemudian hari. Menurut (Nugroho, 2003), kebijakan model elit seperti itu akan hanya berorientasi pada perubahan-perubahan yang bersifat tambal sulam, yang tujuannya masyarakat miskin dibuat sedemikian rupa agar tetap miskin.

Penulis juga akanmembahas fenomena diatas dari berbagai perspektif teori Politik, yaitu Teori Elit, yang dikembangkan oleh Vilfredo Pareto dan Gaetano Mosca, dan Teori Oligarki yang dikembangkan oleh Robert Michels. Yang pertama, penulis menggunakan teori elit yang dikembangkan oleh Vilfredo Pareto dan Gaetano Mosca. Pareto dan Mosca dalam (Gunawan, 2013), berpendapat bahwa elit politik akan memiliki kecenderungan untuk memaksakan kehendaknya melalui cara-cara manipulatif ataupun represif, bahkan dalam negara demokratis sekalipun.

Penulis mengartikan, bahwa elit politik memiliki kecenderungan mengolah sedemikian rupa berbagai kebijakan atau program publik agar yang bersangkutan memiliki kesan atau citra populis. Represif bisa dilakukan elit politik dengan cara menerapkan kebijakan secara paksa kepada publik. Hal tersebut dilakukan untuk menunjukkan kepada publik bahwa yang bersangkutan memiliki power dan legitimasi terhadap sebuah teritori (Negara, Provinsi, Kabupaten/Kota dan Desa). Dalam konteks PKH di Kota dan Kabupaten Malang, memungkinkan bahwa Khofifah sebagai elit politik yang berkepentingan pada pilkada gubernur Jatim 2018 akan melakukan berbagai macam cara untuk mencapai kepentingannya. Termasuk menggunakan PKH sebagai alat politik untuk memanipulasi kepentingan penerima 
bantuan PKH menjadi kepentingan politik perorangan ataupun kelompok tertentu.

Kedua adalah Teori Oligarki. Salah satu ilmuan yang mengembangkan teori oligarki adalah Robert Michels. Istilah paling poluler yang kemukakan Michels untuk melakukan klasifikasi dan indentifikasi elit politik adalah 'hukum besi oligarki'. Istilah 'hukum besi oligarki' adalah kecenderungan sekelompok kecil (segelintir) orang untuk melakukan dominasi (penguasaan) terhadap sumber daya tertentu yang ada disekitarnya (Yosai, 2017)

Oligarki dapat muncul dalam empat dimensi politik, Pertama, dari segi organisasi. Kedua dalam kepemimpinan. Ketiga dalam konteks hubungan organisasi dengan rakyat. Dan yang keempat berada didalam kekuasaan pemerintahan(Connolly, 1988). Menurut (Connolly, 1988) mengkonsepkan elit politik yang ada didalam tubuh birokrasi pemerintahan, partai politik dan kehidupan masyarakat, yang memperkuat penjelasan mengenai kuasa elit politik yang memiliki kuantitas relatif kecil namun memiliki pengaruh dan kuasa dalam kehidupan masyarakat. Dari penjelasan diatas, bahwa praktik oligarki kemungkinan besar terjadi didalam struktur birokrasi pelaksanaan PKH dari pusat hingga daerah.Teori ini juga mendukung fakta yang ada dilapangan, bahwa Bupati sekaligus ketua DPW Partai NasDem Kabupaten Malang, Rendra Kresna mengarahkan para penerima bantuan PKH yang hadir untuk mendukung Khofifah.

\section{Dampak Politisasi PKH}

Penulis membahas dampak dari politisasi PKH menggunakan teori pertukaran sosial. Karena dengan teori pertukaran sosial, kita akan memahami bagaimana secara tidak langsung para penerima PKH akan terikat secara emosional dan politis dengan Khofifah karena PKH dinilai membantu meningkatkan taraf hidup mereka. Interaksi tersebutlah yang akan mengungkap bahwa kebijakan pro-poor seperti PKH sangat rentan dengan muatan politik dalam pelaksanaannya.

Teori pertukaran sosial adalah teori yang berkaitan dengan tindakan maupun perilaku sosial manusia ataupun masyarakat yang memberi atau menukar objek-objek yang mengandung nilai-nilai dalam tatanan sosial-politik tertentu (Wirawan, 2012). Objek yang dipertukarkan antar pihak yang berkepentingan bisa berbentuk materi maupun non-materi. Jika urusan materi, manusia saling tuakrmenukar yang berurusan dengan transaksi keuangan maupun perdagangan. Untuk non-materi, seperti yang menyangkut beban hidup, harapan, dan pencapaian individual maupun komunal. Dengan demikian, konteks pertukaran sosial politik di masyarakat bersifat luas.

Teori pertukaran sosial bisa memiliki efek langsung maupun tidak pada studi perilaku hingga preferensi poitik dan relasi antara masyarakat dan elit politik (Wirawan, 2012). Sehingga teori pertukaran sosial bisa melihat hubungan efek antara perilaku aktor politik pada lingkungan dan dampaknya pada perilaku aktor selanjutnya. Jadi, hubungan ini menjadi dasar pengkondisian pelaku atau proses belajar ketika perilaku dimodifikasi oleh konsekuensi-konsekuensi yang ditimbulkannya.

Dari penjelasan diatas, penulis bisa mengartikan bahwa perilaku politik masyarakat dan elit politik memegang 


\section{Wimmy Halim}

peranan penting dalam menjelaskan hubungan perilaku manusia sebagai bagian dari masyarakat dengan kondisi sosial dan politik yang disesuaikan dengan konteks kedaerahannya. Preferensi maupun perilaku politk masyarakat pada akhirnya terbentuk dengan berbagai cara (Ritzer \& Smart, 2001). Dari sini penulis mengambil kesimpulan bahwa teori pertukaran sosial memberi makna pada perilaku dasar dari manusia bahkan masyarakat dan elit politik, khususnya dalam konteks politisasi PKH yang dilakukan Khoiffah kepada konstituennya, masih mementingkan dampak untung dan rugi secara politik. Untung dan rugi yang dimaksud bukan hanya masalah materi semata, tetapi bagaimana harapan, ide, ataupun pencapaian mereka bisa tercapai atau tidak (W Haliim, 2017).

Efek implementasi PKH di Kota dan Kabupaten Malang ternyata memiliki dampak positif terhadap para penerima bantuan dan Khofifah. Jika para penerima bantuan mendapatkan bantuan materi yang bisa merubah taraf hidupnya, Khofifah mendapatkan citra dan popularitas yang positif sebagai penanggung jawab PKH nasional. Beberapa orang penerima bantuan PKH di Kecamatan Sukun, Kota Malang, seperti bapak Ahmad Lutfi dan Andik Widiyanto mengaku merasakan dampak yang signifikan dari adanya PKH. Untuk urusan preferensi memilihnya dalam pilkada 2018 mendatang mereka juga berani menyatakan diri untuk mendukung Khofifah. Alasannya cukup sederhana, karena mereka menganggap Khofifah telah berhasil melaksanakan PKH dengan baik.

Alasan serupa juga ditunjukkan oleh penerima bantuan PKH di kecamatan lain di Kota dan kabupaten Malang. Seperti
Mochammad Rochim, Widianto (masingmasing berasal dari Kecamatan Blimbing, dan Lowokwaru, Kota Malang), Romy Setriawan dan Novita Anggraeni (masingmasing dari Kecamatan Singosari dan Donomulyo, Kabupaten Malang), yang memiliki kecenderungan yang sama dalam menentukan preferensi memilihnya. Mereka merasa berterima kasih dengan hadirnya PKH yang berjalan baik di Kota dan Kabupaten Malang. Sehingga mereka tidak merasa keberatan untuk mengajak sanak saudara dan keluarga yang sudah cukup umur dalam memilih untuk menentukan pilihan politiknya kepada Khofifah dalam pilkada 2018 mendatang.

Kompleksitas konteks pertukaran sosial didalam pelaksanaan PKH di Kota dan Kabupaten Malang didasarkan pada ide bahwa para penerima bantuan memandang hubungan mereka dengan Khofifah sebagai aktor politik sekaligus penanggung jawab kebijakan. Konteks pertukaran yang mereka pahami adalah menghitung pengorbanan dan membandingkannya dengan penghargaan yang mereka didapatkan dan akhirnya berdampak pada hubungan tersebut. Pengorbanan (cost) adalah pemaknaan mereka dari sebuah hubungan yang memiliki nilai negatif atau merugikan secara materi maupun non-materi. Sedangkan penghargaan (rewards) merupakan pemaknaan mereka dalam sebuah hubungan yang memiliki nilai positif atau menguntungkan secara materi maupun non-materi.

Analisa diatas menunjukkan bahwa Khofifah mendapatkan rewards atas kinerja baiknya dalam mengelola PKH. Para penerima bantuan PKH merasa puas dengan kinerja Khofifah. Sebagai imbalannya, mereka tidak segan untuk 


\section{Wimmy Halim}

menetukan pilihannya kepada Khofifah. Sebagai politisi, inilah kemampuan Khofifah untuk merubah citra positif tersebut menjadi keuntungan politiknya.

Sudut pandang teori pertukaran sosial berpendapat bahwa orang menghitung nilai keseluruhan dari sebuah hubungan dengan mengurangkan pengorbanannya dari penghargaan yang diterimanya (Ritzer \& Smart, 2001). Teori pertukaran sosial memprediksikan bahwa nilai (worth) dari sebuah hubungan mempengaruhi hasil akhir (outcome) atau apakah orang akan meneruskan hubungan atau mengakhirinya. Hubungan yang positif biasanya dapat diharapkan untuk bertahan, sedangkan hubungan yang negatif mungkin akan berakhir. Konteks PKH di Kota dan Kabupaten Malang menjelaskan bahwa terjadi hubungan positif antara penerima bantuan PKH dan Khofifah.

Setelah mengurai dampak politisasi PKH terhadap kecenderungan preferensi pemilih para penerima bantuan, penulis menemukan satu kesimpulan. Dalam konteks PKH sebagai kebijakan pro-poor, Khofifah ternyata memiliki strategipolitik dalam meraih popularitas politik seperti apa yang dilakukan oleh SBY pada tahun 2009 yang lalu. Mereka berdua menggunakan PKH sebagai salah satu alat politiknya.

\section{Merubah Orientasi PKH}

Salah satu cara untuk melepaskan PKH dari komoditas politik para elit yang berkempetingan adalah merubah orientasi PKH yang bersifat bantuan tunai bersyarat lebih berorientasi pemberdayaan. Orientasi yang bersifat bantuan tunai bersyarat hanya mendudukan masyarakat sebagai subjek penerima program saja. Hal inilah yang membuat mereka dalam posisi masyarakat lemah dan rentan terhadap kepentingan politik tertentu. Hal inilah yang menurut penulis bahwa PKH secara sistem harus merubah dirinya kearah pemberdayaan.

Pemberdayaan sebagai suatu konsep dalam pengembangan masyarakat, digunakan secara umum dan luas. Didalam kamus besar bahasa Indonesia pemberdayaan adalah perihal turut berperan serta dalam suatu kegiatan (keikutsertaan). Sedangkan (Isma, 2014) mendefenisikan sebagai setiap proses identifikasi atau menjadi peserta suatu proses komunikasi atau kegiatan bersama dalam suatu situasi sosial tertentu. Definisi lain menyebutkan pemberdayaan adalah kerja sama antara rakyat dan pemerintah dalam merencanakan, melaksanakan, melestarikan, dan mengembangkan hasil pembangunan (Ariantara, Handoko, \& Yusnida, 2014). Dalam konteks PKH, pemberdayaan dalam PKH ditujukan untuk membuat penerima bantuan menjadi masyarakat yang mandiri, tidak hanya sekedar menerima bantuan keuangan secara tunai.

Kita harus memahami bahwa kemiskinan yang ada pada masyarakat tidak semata-mata dikarenakan masalah income mereka. (Hermawan \& Suryono, 2016) menyebutkan, ada tiga penyebab kemiskinan yang ada dalam masyarakat, (1) Problem Kultural. Kemiskinan yang diderita masyarakat miskin terjadi karena turun-menurun. (2) Problem Situasional. Bahwa kemiskinan terjadi karena situasi yang menekan. (3) Problem Interaksional. Masyarakat miskin terjadi karena gabungan dari dua kondisi diatas.

Pemberdayaan pada PKH akan menekankan bahwa segala perkembangan masyarakat dan pembangunan merupakan 


\section{Wimmy Halim}

proses yang hanya bisa berhasil jika hanya dijalankan bukan saja bagi tetapi juga bersama dengan dan oleh rakyat sendiri, terlebih orang miskin. Masyarakat harus ikut secara aktif dalam menentukan serta menjalankan program bantuan dari pemerintah, dan dengan demikian dapat menentukan keadaan hidup mereka sendiri mulai dari saat pengambilan keputusan, pelaksanaan, pengawasannya hingga perawatan suatu program (SUHARTO, 2011).

Kondisi tersebutlah yang belum bisa dipenuhi oleh PKH. Segala bentuk program hanya dibuat secara top-down, sehingga kebijakan pro-poor ini berorientasi instan. Meskipun menekan angka kemiskinan, program ini tidak memberdayakan. Jadi, sangat memungkinkan bagi para penerima bantuan PKH untuk terjerumus kembali kedalam lingkaran kemiskinan.

\begin{tabular}{lll}
\multicolumn{2}{c}{ Maka dari itu pemerintah mutlak } \\
harus & memperhatikan & proses
\end{tabular} pemberdayaan masyarakat yang ada didalam PKH. Pemberdayaan warga ialah proses pengambilan keputusan langsung dalam kebijakan publik. Masyarakat bisa ikut serta secara langsung dalam pengambilan keputusan pada lembaga dan proses pelaksanaan program kemiskinan yang dicanangkan pemerintah, termasuk PKH.

Pemberdayaan harus menempatkan masyarakat tidak hanya sebagai penerima (objek) tetapi sebagai subjek dari program yang dilaksanakan oleh pemerintah (Munandar, 2008). Setiap masyarakat mempunyai hak untuk terlibat dalam pemberdayaan dalam setiap kegiatan yang dapat mempengaruhi masyarakat baik pada tataran lembaga formal maupun pada tataran lembaga non formal. Sehingga masyarakat dengan sendirinya tahu akan hak pemberdayaan dalam pengambilan keputusan. Inilah output yang diinginkan dari PKH yang berorientasi pemberdayaan, yakni masyarakat yang mandiri, berdaya dan mampu lepas diri mereka dari jerat kemiskinan.

Orientasi pemberdayaan akan membawa masyarakat miskin kearah perluasan posisi tawar dan memperkecil ketergantungan mereka dari kelas sosial diatasnya dengan cara memperbesar kemungkinan mereka bisa melakukan diversifikasi usaha (Hermawan \& Suryono, 2016). Pemerintah bisa mewujudkan cara diatas dengan cara memberikan permodalan kepada masyarakat miskin dengan bunga yang rendah dan berkelanjutan, bukannya hanya diberikan bantuan tunai yang rentan dengan muatanmuatan politis. Dengan orientasi pemberdayaan, masyarakat miskin bisa mengembangkan diri mereka agar memiliki keterampilan dan kemampuan untuk memberikan nilai lebih terhadap hidup mereka melalui produk dari usahanya.

PKH wajib memiliki sistem, konsep dan strategi pengentasan kemiskinan yang mendayagunakan semua potensi ekonomi dan sosial untuk dikembangkan secara optimal yang bertumpu pada kepentingan mereka. (Napitupulu, 2015) menyebutnya sebagai "People Center Development" (PCD). PCD memiliki 6 karakteristik pokok pendekatan pengentasan kemiskinan yang berpusat pada masyarakat miskin, (1) adanya keputusan dan inisiatif untuk memenuhi kebutuhan mereka yang dibuat di tingkat lokal, (2) fokus utamanya adalah memperkuat kemampuan rakyat miskin dalam memunuhi kebutuhannya, adanya toleransi terhadap perbedaan, (4) 


\section{Wimmy Halim}

adanya proses pembelajaran sosial yang didalamnya terdapat interaksi kolaboratif antara birokrasi dan komunitars mulai dari proses perencanaan sampai dengan evaluasi program, (5) budaya kelembagaan yang kondusif dan berorientasi pemberdayaan, dan yang terakhir (6) adanya proses pembentukan jaringan koalisi dan komunikasi antara birokrasi dan LSM lokal, satuan organisasi tradisional, dsb. (Yasa, 2008)

\section{SIMPULAN DAN SARAN}

PKH merupakan program top-down yang rentan digunakan penguasa untuk kepentingan-kepentingan tertentu, semisal untuk mendongkrak elektabilitas dan popularitas elit politik dalam mendekati momen pilkada gubernur jawa timur. Kota dan Kabupaten Malang adalah salah satu contoh bahwa PKH digunakan oleh elit politik guna pilkada gubernur 2018. Hal tersebut terjadi karena mereka mengetahui bahwa PKH adalah program dengan orientasi bantuan langsung tunai yang hanya berorientasi menanggulangi kemiskinan secara instan, tidak sampai dengan akarnya.

Pemerintah harus merubah arah atau orientasi PKH menjadi pemberdayaan masyarakat khusus masyarakat miskin. Ketika PKH sudah merubah orientasinya menjadi pemberdayaan, maka PKH bisa lepas dari genggaman elit-oligarki yang berhasrat untuk memanfaatkan PKH dalam momentum pemilu. Orientasi pemberdayaan memiliki kecenderungan capaian (goal) jangka panjang dan membentuk masyarakat miskin menuju masyarakat yang mandiri dan berdaya. Dampaknya, PKH akan menjadi salah satu program jangka panjang yang tidak terlalu diminati oleh elit-oligarki dengan ketertarikan terhadap program-program kemiskinan jangka pendek ataupun instan namun memiliki dampak peningkatan signifikan terhadap tingkat elektabilitas dan popularitasnya.

\section{DAFTAR PUSTAKA}

Ambarwati, S. (2014). HUBUNGAN ANTARA NIAT PESERTA DENGAN IMPLEMENTASI KOMITMEN PROGRAM KELUARGA HARAPAN KOMPONEN KESEHATAN. Jurnal Promosi Kesehatan. Retrieved from http://www.journal.unair.ac.id/filerPD F/jupromkesb684d4a347full.pdf

Ariantara, Y., Handoko, H., \& Yusnida, Y. (2014). Analisis Partisipasi Masyarakat terhadap Perencanaan Pembangunan di Kecamatan Pondok Kelapa Kabupaten Bengkulu Tengah. Retrieved from http://repository.unib.ac.id/id/eprint/ 9488

Avirista Midaada. (2017). Mensos Khofifah Bagikan Bantuan PKH dan BPNT di Kabupaten Malang: Okezone News. Retrieved November 25, 2017, from https://news.okezone.com/read/2017 /11/20/519/1817496/mensoskhofifah-bagikan-bantuan-pkh-danbpnt-di-kabupaten-malang

Connolly, W. (1988). Political theory and modernity.

Gunawan, D. H. (2013). Perubahan Sosial di Pedesaan Bali. Retrieved from http://repository.uksw.edu/handle/12 3456789/3345

Haliim, W. (2016). Poverty Reduction for Extremely Poor Households of Malang City by the Implementation of Program Keluarga Harapan. Jurnal Bina Praja: Home Affairs, 8(2), 331-340. Retrieved from

http://binaprajajournal.com/ojs/index .php/jbp/article/view/221

Hermawan, Y., \& Suryono, Y. (2016). Partisipasi masyarakat dalam 


\section{Wimmy Halim}

penyelenggaraan program-program pusat kegiatan belajar masyarakat Ngudi Kapinteran. Jurnal Pendidikan Dan Pemberdayaan Masyarakat, 3(1), 97.

https://doi.org/10.21831/jppm.v3i1.8 111

Isma, C. (2014). Akuntabilitas, Partisipasi Masyarakat, dan Transparansi Kebijakan Publik sebagai Pemoderating Hubungan Pengetahuan Dewan tentang Anggaran dan. Repository.Unib.Ac.Id. Retrieved from http://repository.unib.ac.id/id/eprint/ 6668

Lewis, S. C. (2015). Qualitative inquiry and research design: Choosing among five approaches. Journals.Sagepub.Com. Retrieved from http://journals.sagepub.com/doi/abs/ 10.1177/1524839915580941

M. Sulton Mawardi, Ruhmaniyati, Ana Rosidha Tamyis, Syaikhu Usman, Asep Kurniawan, B. (2017). Kajian Awal Pelaksanaan Program e-Warong KubePKH / The SMERU Research Institute. Retrieved from http://www.smeru.or.id/id/content/k ajian-awal-pelaksanaan-program-ewarong-kube-pkh

Matualage, P. (2015). Implementasi Kebijakan Program Keluarga Harapan di Kota Manado (Studi Kasus di Kecamatan Tuminting. Jurnal POLITICO. Retrieved from https://ejournal.unsrat.ac.id/index.ph $\mathrm{p} /$ politico/article/view/7923

Miski, Deny Rahman, Y. E. I. (2017). 2018, Kabupaten Malang Dapat Tambahan 31 Ribu Penerima PKH - MalangVoice. Retrieved November 17, 2017, from https://malangvoice.com/2018kabupaten-malang-dapat-tambahan31-ribu-penerima-pkh/

Muhammad Aminudin. (2017). "Kampanye" Bupati Malang untuk Khofifah Saat Pembagian PKH. Retrieved November 20, 2017, from https://news.detik.com/berita/d- 3734470/kampanye-bupati-malanguntuk-khofifah-saat-pembagianpkh?_ga $=2.152117881 .1781767161 .15$ 11140187-847572155.1508732124

Mulyadi, M. (2011). Penelitian kuantitatif dan kualitatif serta pemikiran dasar menggabungkannya. Jurnal Studi Komunikasi. Retrieved from http://www.academia.edu/download/ 39420026/ipi198551.pdf

Munandar. (2008). Peran Negara dalam Penguatan Program Pemberdayaan Masyarakat. Jurnal Kajian Politik, Dan Masalah Pembangunan, 4(1), 151-162. Retrieved from http://sps.unas.ac.id:8080/publikasi/P 151-162 Peran Negara.pdf

Napitupulu, H. D. M. (2015). Efektivitas Musyawarah Perencanaan Pembangunan (MUSRENBANG) Kecamatan Senapelan Kota Pekanbaru Tahun 2013. Jom.Unri.Ac.Id. Retrieved from

https://jom.unri.ac.id/index.php/JOMF SIP/article/view/5485

Nugroho, R. (2003). Kebijakan Publik: Formulasi, Implementasi dan Evaluasi. Jakarta: Elex Media Komputindo.

Rahayu, A. (2015). Program Keluarga Harapan (Kampanye Permanen SBY dan Partai Demokrat?) oleh Achmad Rahayu - Kompasiana.com. Retrieved June 25, 2015, from https://www.kompasiana.com/achma drahayu/program-keluarga-harapankampanye-permanen-sby-dan-partaidemokrat_550d92b0813311c42ab1e4 $\mathrm{e} 0$

Rahmadiani, T. (2016). Implementasi Program Keluarga Harapan bagi Rumah Tangga Sangat Miskin (RTSM)(Studi Implementasi Keputusan Walikota Malang Nomor 188.45/159/35.73. 112. Jurnal Administrasi Publik. Retrieved from http://administrasipublik.studentjour nal.ub.ac.id/index.php/jap/article/vie $\mathrm{w} / 1254$

Ritzer, G., \& Smart, B. (2001). Handbook of 


\section{Wimmy Halim}

social theory. Retrieved from https://www.google.com/books?hl=id \&lr=\&id=RkuylW6_Q-

AC\&oi=fnd\&pg=PP1\&dq=Ritzer, + Georg e.+Smart,+Barry.+(2010).+Handbook+ of+Social+Theory.+London+\%3B+Sage. \&ots=YGY2IW2zcP\&sig=mjFl8ZKIp1E1 9h5SxYjCOF8fB9k

Rosfadhila, M Toyamah, N. S. (2011). Kajian Cepat Pelaksanaan Program Bantuan Langsung Tunai (BLT) 2008 dan Evaluasi Penerima Program BLT 2005 di Indonesia. Smeru.or.Id. Retrieved from

http://www.smeru.or.id/sites/default/ files/publication/blt2008_ind.pdf

SUHARTO, R. (2011). Rekonstruksi Birokrasi Pemerintah Daerah dalam Pengelolaan Sumber Daya Alam Menuju Keberlanjutan Ekologi. Retrieved from http://eprints.undip.ac.id/40822/

Surya Malang. (n.d.). Tahun Depan, Penerima Program Keluarga Harapan di Kota Malang Naik 1800 Kepala Keluarga - Surya Malang. Retrieved from

http://suryamalang.tribunnews.com/2 017/11/12/tahun-depan-penerimaprogram-keluarga-harapan-di-kotamalang-naik-1800-kepala-keluarga

Tribunnews. (n.d.). Mensos Khofifah Resmikan e-Warung KUBE di Malang, Foto 5 \#1658776 - Tribunnews.com. Retrieved November 5, 2017, from http://www.tribunnews.com/images/ editorial/view/1658776/mensoskhofifah-resmikan-e-warung-kube-dimalang

W Haliim. (2017). Perspektif Pertukaran Sosial dalam Perilaku Politik Masyarakat pada Pilkada Kota Malang 2013. Politik Indonesia: Indonesian Political Science Review, 2(2), 201-226.
Retrieved from https://journal.unnes.ac.id/nju/index. php/jpi/article/download/8950/6423

Wirawan, D. (2012). Teori-teori Sosial dalam Tiga Paradigma: fakta sosial, definisi sosial, dan perilaku sosial. Retrieved from https://www.google.com/books?hl=id \&lr $=$ \&id=9KRPDwAAQBAJ\&oi=fnd \&pg $=$ PA169\&dq=Wirawan,+I.B.+(2012).+T eori-

Teori+Sosial+Dalam+Tiga+Paradigma+ :+Fakta+Sosial,+Definisi+Sosial, + dan $+\mathrm{P}$ erilaku+Sosial.+Jakarta:+Kencana\&ots= 8lhcD1Fxok\&sig=UTygh6uKnNYJ8znqz7znWENhME

Yasa, M. (2008). Penanggulangan Kemiskinan Berbasis Partisipasi Masyarakat di Provinsi Bali. Jurnal Ekonomi Dan Sosial. Retrieved from https://ojs.unud.ac.id/index.php/input /article/view/3187

Yosai, S. (2017). The Influence of Parental Involvement, Classified By Parent's Demographic Factors, and Current Education Policy on Student Achievement in High School in NongChok District, Bangkok, Thailand. JKAP (Jurnal Kebijakan Dan Administrasi Publik), 20(2), 1. https://doi.org/10.22146/jkap.12518

\section{PROFIL SINGKAT}

Wimmy Haliim, lahir di Kediri, 4 Juli 1990. Penulis merupakan Dosen Ilmu Politik di lingkungan Fakultas Ilmu Sosial dan Ilmu Politik, Universitas Brawijaya. Penulis menyelesaikan studi S1 Ilmu Politik dan S2 Ilmu Sosial di FISIP-UB. Di prodi ilmu politik penulis menjabat sebagai koordinator konsentrasi studi 'Politik Kebijakan dan Tata Kelola Pemerintahan'. 